\title{
MODEL PROJECT BASED LEARNING (PJBL) TERINTEGRASI STEM UNTUK MENINGKATKAN PENGUASAAN KONSEP DAN AKTIVITAS BELAJAR SISWA
}

\author{
Ines Dwi Astuti ${ }^{1)}$, Toto $^{2)}$, Lia Yulisma ${ }^{3)}$ \\ ${ }^{1}$ Prodi Pendidikan Biologi, FKIP Universitas Galuh Ciamis \\ Email: inesdwiastuti@gmail.com \\ ${ }^{2}$ Prodi Pendidikan Biologi, FKIP Universitas Galuh Ciamis \\ Email: totounigal_cms@yahoo.com \\ ${ }^{3}$ Prodi Pendidikan Biologi, FKIP Universitas Galuh Ciamis \\ Email: goli_yulisma31@yahoo.co.id
}

APA Citation: Astuti I. D., Toto \& Yulisma, L. (2019). Model Project Based Learning (PjBL) Terintegrasi STEM Untuk Meningkatkan Penguasaan Konsep Dan Aktivitas Belajar Siswa. Quagga: Jurnal Pendidikan dan Biologi, 11(2), 93-98. doi: 10.25134/quagga.v11i2.1915.

Received: $27-07-2019$

Accepted: 29-07-2019

Published: 30-07-2019

Abstrak: Penelitian ini bertujuan untuk mengetahui Model Project Based Learning (PjBL) Terintegrasi STEM dalam meningkatkan Penguasaan Konsep dan Aktivitas Belajar Siswa. Populasi penelitian ini adalah siswa kelas X IPA sebuah SMA Negeri di Kabuaten Ciamis. Sampel yang digunakan yaitu kelas X IPA2 sebanyak 21 siswa yang dipilih dari populasi dengan menggunakan teknik purposive sampling. Metode penelitian ini yaitu metode Pre-Eksperimental Design. Desain pada penelitian ini yaitu one-Group Pretest-Posttest Design. Instrumen yang digunakan adalah instrumen test penguasaan konsep yang terdiri dari 20 soal dengan pokok bahasan Ekosistem dan instrumen lembar observasi aktivitas belajar siswa. Teknik analisis data yang dipakai pada penelitian ini uji z. Hasil penelitian disimpulkan bahwa model Project Based Learning (PjBL) terintegrasi STEM dapat meningkatkan penguasaan konsep dan aktivitas belajar.

Kata kunci : Project Based Learning; STEM; Penguasaan Konsep Siswa; Aktivitas Belajar Siswa

\begin{abstract}
This study aims to determine the STEM Integrated Project Based Learning (PjBL) model in improving Mastery of Concepts and Student Learning Activities. The population of this study was the tenth grade students of Natural Science in a State High School in Ciamis District The sample used was the X class of Science as many as 21 students selected from the population using purposive sampling technique. This research method is the Pre-Experimental Design method. The design of this study is one-group pretest-posttest design. The instrument used is the concept mastery test instrument consisting of 20 questions with the subject matter of the Ecosystem and the observation sheet of student learning activities. The analysis used is the z test. The results of the study concluded that the STEM integrated Project Based Learning (PJBL) model can improve mastery of concepts and learning activities.
\end{abstract}

Keywords: Project Based Learning; STEM; Mastery of Student Concepts; Student Learning Activities

\section{PENDAHULUAN}

Pada era abad 21 ini pendidikan semakin berkembang dan modern. Pendidikan dan pembelajaran mesti sesuai dengan karakteristik abad 21 ini. Para ahli berpendapat bahwa pendekatan dalam pembelajaran sains (IPA) yang linier dengan karakteristik abad 21 adalah pendekatan STEM yang merupakan akronim dari Science, Technology, Engineering, and Mathematics. STEM membuat siswa dapat memecahkan permasalahan menjadi lebih baik, inovator, inventors, mandiri, berpikir logis, sehingga STEM cocok diterapkan pada pembelajaran di era globalisasi ini. Pendekatan STEM membantu peserta didik dan guru dalam memecahkan masalah dalam pembelajaran. Beberapa manfaat dari pendekatan STEM membuat peserta mampu menyelesaikan dengan lebih baik, inovator, investor, independen, pemikir logis, dan melek huruf (Toto, 2019).

Bagaimana penguasaan konsep sains (IPA) dan motivasi belajar siswa dalam menyongsong masa depan di era ini? Untuk menjawab pertanyaan ini peneliti mengadakan stuudi pendahuluan dengan mewawancarai guru biologi pada sebuah SMA Negeri di Kabupaten Ciamis. Hasil wawancara terungkap bahwa nilai ulangan biologi sebagian besar belum mencapai KKM (kriteria ketuntasan minimum) yang telah ditetapkan di sekolah itu yaitu 60,00. Dengan 
Quagga: Jurnal Pendidikan dan Biologi Volume 11, Nomor 2, Juli 2019

demikian hal tersebut menunjukkan bahwasannya penguasaan konsep siswa terhadap materi yang disampaikan masih kurang, sehingga siswa tidak mampu menyelesaikan soal-soal yang diberikan. Selain itu dalam pembelajaran guru menjadi pusat sumber belajar (teacher center), siswa lebih banyak bersikap pasif sehingga keterlibatan siswa dalam proses pembelajaran cenderung rendah. Siswa cenderung mendengarkan apa yang guru sampaikan saja, sehingga pembelajaran menjadi monoton.

Setiap siswa pada dasarnya memiliki potensi yang berbeda-beda, hal ini dapat menyebabkan kesalahan penguasaan konsep pada masingmasing siswa. Sehingga dapat menjadi salah satu penghambat pencapaian tujuan pembelajaran. Agar siswa mampu memecahkan masalah sebagai tujuan pembelajaran, maka dibutuhkan penerapan model yang sesuai dengan materi dan tujuan pembelajaran. Salah satunya yaitu model Project Based Learning (PjBL).

Model PjBL diintegrasikan dengan STEM. Pengintegrasian ini diharapkan peserta didik mempunyai literasi sains dan teknologi, yang ditingkatkan melalui kegiatan membaca, menulis, mengamati dan melakukan sains, serta mampu meningkatkan kompetensi yang mereka miliki untuk diterapkan saat menghadapi permasalahan dalam kehidupan sehari-hari yang berkaitan dengan bidang ilmu STEM. Hubungan antara sains dan teknologi maupun ilmu lain dalam pembelajaran sains tidak dapat dipisahkan. STEM merupakan disiplin ilmu yang berkaitan erat satu sama lain. Sains membutuhkan matematika untuk mengolah data, sedangkan teknologi dan teknik merupakan aplikasi dari sains.

Siswa yang memperoleh pembelajaran berbasis proyek memiliki penguasaan konsep dan hasil belajar yang lebih baik. Model pembelajaran Project Based Learning (PjBL) sangat penting untuk meningkatkan kualitas aktivitas siswa dan mengandung beberapa proses pembelajaran yang berbeda. Penerapan model Project Based Learning (PjBL) akan mendorong peningkatan kemampuan siswa dalam belajar konseptual.

Berdasarkan uraian di atas, maka penulis melakukan penelitian untuk mengetahui Model Project Based Learning (PjBL) terintegrasi STEM dalam meningkatkan penguasaan konsep dan aktivitas belajar siswa.

\section{METODOLOGI PENELITIAN}

p-ISSN 1907-3089, e-ISSN2651-5869

https://journal.uniku.ac.id/index.php/quagga

Metode yang digunakan pada penelitian ini adalah Pre-Experimental dengan one-Group Pretest-Posttest Design. Populasi penelitian sebanyaak enam kelas pada sebuah SMA Negeri di Kabupaten Ciamis, dan sampel satu kelas yaitu X IPA2 yang diambil dengan Teknik random sampling. siswa. Instrumen yang digunakan untuk test penguasaan konsep adalah tes tertulis/tes objektif bentuk pilihan ganda. Instrumen Aktivitas Belajar adalah lembar observasi. Teknik analisis data yang dipakai adalah statistika deskriptif, uji normalitas dan uji $\mathrm{z}$.

\section{HASIL DAN PEMBAHASAN}

Ringkasan hasil penelitian mengenai pengasaan konsep disajikan pada tabel 1

Tabel.1 Statistik data penelitian

\begin{tabular}{lccc}
\hline Kriteria & $\begin{array}{c}\text { Pretes } \\
t\end{array}$ & $\begin{array}{c}\text { Posttes } \\
t\end{array}$ & $\begin{array}{c}N- \\
\text { gain }\end{array}$ \\
\hline Rata-Rata & 47,00 & 83,25 & 70,91 \\
Nilai & 60 & 95 & 90,91 \\
Max & 35 & 70 & 44,44 \\
Nilai Min & & & \\
\hline
\end{tabular}

\section{Uji Normalitas Data}

Hasil uji normalitas menunjukan bahwa data normal.

\section{Uji hipotesis $\mathrm{z}$}

Dapat disimpulkan bahwa disimpulkan bahwa penggunaan model pembelajaran $\mathrm{PjBL}$ terintegrasi STEM dapat berpengaruh terhadap penguasaan konsep siswa.

\section{N-Gain}

Dapat disimpulkan bahwa adanya peningkatan penguasaan konsep dengan menggunakan model Project Based Learning terintegrasi STEM.

\section{Aktivitas Belajar Siswa}

Ringkasan data hasil observasi aktivitas siswa dengan model pembelajaran $\mathrm{PjBL}$ terintegrasi STEM disajikan dalam tabel.2

Tabel.2 Rekapitulasi Hasil Aktivitas Siswa

\begin{tabular}{llcc}
\hline \multirow{2}{*}{ Komponen } & \multicolumn{1}{c}{ Indikator } & \multicolumn{2}{c}{ Aktivitas Siswa } \\
\cline { 3 - 4 } & $\begin{array}{l}\text { Mengajukan } \\
\text { pendapat saat diskusi } \\
\text { kelompok }\end{array}$ & 85,0 & $\begin{array}{c}\text { Kriteria } \\
\text { Sangat } \\
\text { aktif }\end{array}$ \\
& $\begin{array}{l}\text { Bertanya berkaitan } \\
\text { dengan materi }\end{array}$ & 87,5 & $\begin{array}{c}\text { Sangat } \\
\text { aktif }\end{array}$ \\
& $\begin{array}{l}\text { pelajaran } \\
\text { Berdiskusi untuk }\end{array}$ & & Sangat \\
& $\begin{array}{l}\text { memecahkan } \\
\text { masalah }\end{array}$ & 82,5 & aktif \\
Mental & $\begin{array}{l}\text { Berani } \\
\text { mengeluarkan }\end{array}$ & 85,0 & $\begin{array}{c}\text { Sangat } \\
\text { aktif }\end{array}$ \\
\hline
\end{tabular}


Quagga: Jurnal Pendidikan dan Biologi Volume 11, Nomor 2, Juli 2019

\begin{tabular}{|c|c|c|c|}
\hline \multirow{3}{*}{$\begin{array}{l}\text { Writting } \\
\text { activity }\end{array}$} & pendapat & & \\
\hline & $\begin{array}{l}\text { Mencatat mengenai } \\
\text { materi pelajaran } \\
\text { berdasarkan projek } \\
\text { yang dibuat }\end{array}$ & 90,0 & Sangat aktif \\
\hline & $\begin{array}{l}\text { Siswa menuliskan } \\
\text { hasil diskusi }\end{array}$ & 85,0 & Sangat aktif \\
\hline \multirow{2}{*}{$\begin{array}{l}\text { Visual } \\
\text { activity }\end{array}$} & $\begin{array}{l}\text { Siswa mengamati } \\
\text { gambar/foto tentang } \\
\text { nteraksi antar } \\
\text { organisme yang } \\
\text { ditampilkan guru pada } \\
\text { awal pembelajaran }\end{array}$ & 85,0 & Sangat aktif \\
\hline & $\begin{array}{l}\text { Siswa mengamati } \\
\text { berbagai komponen } \\
\text { ekosistem pada projek } \\
\text { miniatur ekosistem } \\
\text { yang dibuatnya }\end{array}$ & 87,5 & Sangat aktif \\
\hline \multicolumn{2}{|c|}{ Rata-rata skor aktivitas } & 85,93 & $\begin{array}{l}\text { Sangat } \\
\text { aktif }\end{array}$ \\
\hline
\end{tabular}

Rata-rata skor aktivitas belajar siswa dari seluruh indikator tersebut yaitu 85,93 dengan kategori sangat aktif.

Penguasaan konsep siswa mengalami peningkatan $70,91 \%$ (tinggi). Berdasarkan hasil uji normalitas dengan uji $\chi 2$ dapat diperoleh $\chi 2$ hitung $<\chi 2$ tabel yaitu $5,106<5,99$. Berdasarkan perhitungan uji hipotesis $\mathrm{z}$, dapat diketahui bahwa zhitung > ztabel., sehingga disimpulkan bahwa model pembelajaran PjBL terintegrasi STEM mampu meningkatkan penguasaan konsep siswa. Hal tersebut sesuai dengan penelitian Sastrika et al. (2013) yang menunjukkan bahwa pembelajaran proyek dapat meningkatkan penguasaan konsep. Temuan ini diperkuat oleh hasil penelitian yang dilakukan Furi et al. (2018) bahwa model pembelajaran PjBL terintegrasi STEM secara signifikan meningkatkan penguasaan konsep terhadap mata pelajaran yang diajarkan, selain itu hasil penelitian oleh Siregar (2016) mengatakan bahwa pendekatan yang berorientasi pada siswa secara umum lebih efektif dalam meningkatkan minat dan penguasaan konsep siswa baik pada jenjang perguruan tinggi (mahasiswa), ataupun jenjang dibawahnya (siswa). Pada penilaian penguasaan konsep menunjukkan bahwa setelah adanya perlakuan diterapkannya model pembelajaran berbasis proyek terintegrasi STEM di kelas eksperimen memiliki nilai rata-rata yang lebih tinggi.

Project Based Learning dan STEM (Science, Technology, Engineering, and Mathematics) memiliki kelebihan. Pada project based learning peserta didik mampu memahami konsep dengan membuat produk, dan pada pembelajaran STEM terjadi proses perancangan dan redesign (engineering design process) sehingga membuat siswa menghasilkan produk terbaiknya. Integrasi
p-ISSN 1907-3089, e-ISSN2651-5869

https://journal.uniku.ac.id/index.php/quagga

aspek-aspek STEM memberikan dampak positif terhadap proses belajar mengajar terutama dalam hal peningkatan hasil belajar siswa di bidang sains dan teknologi (Becker \& Park, 2011), dengan hal tersebut PjBL berbasis STEM berpengaruh terhadap penguasaan konsep siswa dan aktivitas siswa.

Pada pelaksanaannya, peserta didik diberikan kerangka proyek yang mampu menuntun mereka menemukan solusi masalah, sehingga siswa mampu menyelesaikan proyek sesuai dengan waktu yang sudah ditentukan sebelumnya. Pembelajaran berbasis proyek dapat memberikan pengetahuan yang lebih bermakna. Hal ini sejalan dengan penelitian Na'imah et all. (2015) bahwa pembelajaran berbasis proyek tidak hanya sekedar memberi pengetahuan kepada siswa namun juga menjadikan pengetahuan itu lebih bermakna melalui kegiatan proyek yang dapat mengubah konsep yang bersifat abstrak menjadi nyata, sehingga konsep tersebut dapat diingat dalam jangka panjang oleh siswa (Lukman et al., 2015).

Ungkapan di atas dibuktikan dengan meningkatnya penguasaan konsep siswa. Jika ditinjau dari Kriteria Ketuntasan Minimal (KKM) yang ditentukan sekolah yaitu 60, hasil belajar peserta didik di kelas eksperimen telah mencapai KKM setelah diberikan treatmeant yaitu 83,25 . Peningkatan pada penguasaan konsep ini terjadi karena adanya faktor-faktor yang mempengaruhi diantaranya yaitu faktor internal siswa berupa minat yang tinggi terhadap materi yang diajarkan. Siswa terlibat aktif dan inovatif saat merancang proyek, memiliki kerjasama yang baik untuk pemecahan masalah, faktor eksternal berupa keadaan lingkungan sekitar yang menarik untuk dipelajari dan model pembelajaran, penggunaan model pembelajaran yang mengantar siswa dalam mencapai tujuan yang diharapkan (Slameto, 2010).

Penggunaan pendekatan STEM dalam pembelajaran mampu memecahkan masalah, membuat pembaruan (innovation), menemukan/merancang hal baru. Hal ini sesuai dengan pernyataan Devi (2018) yang mengungkapkan bahwa STEM mampu meningkatkan keterampilan belajar dan berinovasi, memecahkan masalah, menemukan/ merancang hal baru, memahami diri, melakukan pemikiran logis dan menguasai teknologi. Pendekatan ini difokuskan pada dunia nyata dan masalah otentik sehingga peserta didik belajar untuk merefleksikan proses pemecahan masalah. Pembelajaran STEM membuat peserta didik 
Quagga: Jurnal Pendidikan dan Biologi Volume 11, Nomor 2, Juli 2019

memiliki wawasan yang mendalam, bersifat dinamis dan kreatif, sehingga dapat menciptakan generasi unggul (Ferdiansyah, 2015).

STEM diaplikasikan secara terintegrasi untuk mengembangkan produk, proses, dan sistem yang bermanfaat bagi kehidupan seharihari, sejalan dengan penelitian yang dilakukan Mayasari et al., (2014) bahwa dengan adanya pembelajaran STEM, siswa memiliki literasi sains dan teknologi yang nampak dari membaca, menulis, mengamati, serta melakukan sains sehingga bisa dijadikan acuan dalam memecahkan permasalahan dalam kehidupan sehari-hari yang terkait dengan bidang ilmu STEM dan sebagai bekal hidup bermasyarakat. Siswa yang belajar dengan pendekatan STEM akan dapat memiliki pengetahuan, sikap, dan keterampilan untuk mengidentifikasi masalah terkait materi yang diajarkan. kepercayaan diri siswa meningkat dalam menjawab pertanyaan dan permasalahan karena adanya bukti nyata. STEM mampu meningkatkan kemampuan kognitif siswa sampai mencipta. Pembelajaan STEM membuat siswa lebih bebas bergerak dinamis mengikuti minatnya dan kemampuan untuk memecahkan masalah dengan lebih kreatif diintegrasikan dengan disiplin ilmu lain.

Pada hakikatnya, pembelajaran berbasis proyek merupakan suatu model pembelajaran yang mengharuskan siswa untuk berpartisipasi secara aktif baik individu ataupun secara berkelompok, karena melalui kerjasama dalam kelompok akan melibatkan peserta didik dalam proses investigasi pemecahan masalah (Na'imah et al. 2015). Melalui pembelajaran berbasis proyek aktivitas dan hasil belajar dapat meningkat (Addiin et al., 2014). Hal ini yang menjadi landasan dari aspek penilaian aktivitas selama proses pembelajaran berlangsung menunjukkan bahwa siswa mampu melaksanakan setiap tahapan proyek dengan baik sesuai dengan kriteria penilaian yang telah ditetapkan.

Selain itu, temuan penelitian berkenaan dengan aktivitas belajar siswa menyimpulkan bahwa dari setiap aspek pengamatan ternyata memiliki kriteria yang baik pada kebanyakan siswa yang belajar dengan penerapan pembelajaran berbasis proyek. Dalam pelaksanaannya, model project based learning (PjBL) ini diaplikasikan dengan metode percobaan berupa proyek, demonstrasi, diskusi dan tanya jawab. Dengan model pembelajaran berbasis proyek yang diterapkan dapat menjadikan siswa mampu mengaplikasikan
p-ISSN 1907-3089, e-ISSN2651-5869

https://journal.uniku.ac.id/index.php/quagga

materi yang didapatkan selama proses belajar mengajar kedalam kehidupan sehari-hari (Na'imah et al., 2015).

Model pembelajaran berbasis proyek sangat berpotensi membuat pengalaman belajar yang lebih menarik bagi peserta didik, dimana siswa dituntut untuk berpikir kreatif serta mampu bekerja dalam tim atau kelompok untuk membentuk kreativitas dan pengalaman belajar siswa dengan proyek yang nyata.

Penggunaan model PjBL memiliki keuntungan menurut (Kurniasih, 2014) yaitu dapat meningkatkan motivasi belajar peserta didik untuk belajar mendorong mereka melaksanakan pekerjaan penting, serta membuat siswa menjadi lebih aktif dan mampu memecahkan masalah yang kompleks, meningkatkan kolaborasi, menyediakan pengalaman belajar yang melibatkan peserta didik secara kompleks dan dirancang berkembang sesuai dunia nyata.

Data aktivitas belajar siswa diperoleh dari pengisian lembar observasi setelah pembelajaran selesai dilakukan dengan indikator (1) Mengajukan pendapat saat diskusi kelompok (2) Bertanya berkaitan dengan materi pelajaran (3) Berdiskusi untuk memecahkan masalah (4) Berani mengeluarkan pendapat (5) Mencatat mengenai materi pelajaran berdasarkan projek yang dibuat (6) Siswa menuliskan hasil diskusi (7) Siswa mengamati gambar/foto tentang interaksi antar organisme yang ditampilkan guru pada awal pembelajaran (8) Siswa mengamati berbagai komponen ekosistem pada projek miniatur ekosistem yang dibuatnya. Data aktivitas belajar siswa dapat dilihat pada grafik 1.

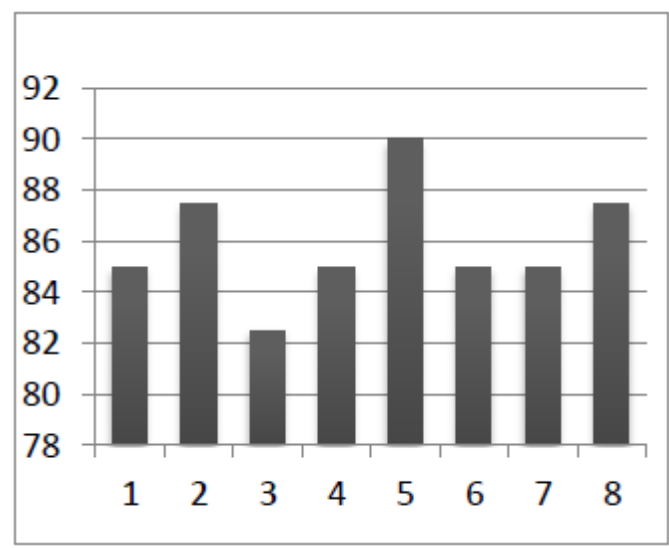

Gambar.1 Grafik Aktivitas Belajar Siswa

Berdasarkan gambar 1 skor yang diperoleh dari setiap indikator berbeda-beda, sehingga memperoleh rata-rata skor yaitu mencapai 
Quagga: Jurnal Pendidikan dan Biologi

Volume 11, Nomor 2, Juli 2019

85,93\% dengan kategori sangat aktif. Hal ini menunjukkan bahwa model pembelajaran PjBL terintegrasi STEM sangat tepat untuk pembelajaran, sejalan dengan penelitian Titu (2015) menyatakan bahwa PjBL terintegrasi STEM sangat tepat diterapkan dalam pembelajaran karena mampu berpengaruh terhadap interaksi siswa dengan lingkungannya. Model pembelajaran ini memiliki kelebihan untuk meningkatkan aktivitas belajar siswa, karena menuntut siswa untuk aktif menyelesaikan suatu proyek dan diterapkan dalam kehidupan sehari-hari.

Proses pembelajaran dengan pendekatan STEM pada aktivitas belajar siswa lebih terlihat peningkatannya pada tahap Discovery dan Application (Jauhariyyah, 2017). Discovery yaitu tahap penemuan yang umumnya mengikutsertakan proses menjembatani research dan informasi yang diketahui dalam penyusunan proyek. Ketika peserta didik mulai belajar mandiri dan menentukan apa yang masih belum diketahui. Siswa dibagi menjadi kelompok kecil untuk menyajikan solusi yang mungkin untuk menyelesaikan masalah, berkolaborasi, serta membangun kerjasama antar individu dalam kelompok. Selanjutnya adalah tahap Application yang bertujuan untuk menguji produk/solusi dalam memecahkan masalah. Pada beberapa kasus, peserta didik menguji produk yang mereka buat dari ketentuan yang sudah ditetapkan, hasil yang diperoleh dipergunakan untuk memperbaiki langkah sebelumnya. Di model lain, pada tahapan ini peserta didik belajar konteks yang lebih luas di luar STEM atau menghubungkan antara disiplin bidang STEM.

Berdasarkan hasil analisis observasi siswa, dapat disimpulkan bahwa siswa lebih aktif dalam pembelajaran ekosistem dengan menerapkan model Project based Learning karena mengajukan pendapat, bertanya, dan berdiskusi untuk memecahkan masalah dalam kehidupan sehari-hari dan dapat membuat siswa lebih mudah dalam memahami materi.

\section{SIMPULAN}

Berdasarkan data penelitian dan analisis data dapat disimpulkan bahwa model Project Based Learnng (PjBL) terintegrasi STEM dapat meningkatkan penguasaan konsep siswa pada materi Ekosistem dengan kategori (tinggi). Dan model Project Based Learning (PjBL) terintegrasi STEM dapat meningkatkan aktivitas siswa dalam kategori (sangat aktif).

\section{Rekomendasi}

p-ISSN 1907-3089, e-ISSN2651-5869

https://journal.uniku.ac.id/index.php/quagga

Berdasarkan penelitian maka direkomendasikan hal-hal sebagai berikut:

a. Pembelajaran dengan menggunaan model pembelajaran project based learning terintegrasi STEM membutuhkan waktu yang lama dalam pelaksanaannya. Karena, semakin banyak stimulus yang diberikan kepada siswa semakin banyak pula respon berupa pertanyaan balik. Sehingga, guru harus mampu mengatur waktu dengan baik.

b. Pembelajaran dengan menggunakan model PjBL terintegrasi STEM harus disesuaikan dengan materi dan situasi yang mendukung. Dalam hal ini penggunaan model PjBL harus membutuhkan banyak waktu untuk menyelesaikan masalah dan menghasilkan produk, selain itu tidak sesuai untuk siswa yang mudah menyerah dan tidak memiliki keterampilan.

c. Sekolah perlu menerapkan pembelajaran menggunakan model PjBL terintegrasi STEM pada sub materi lain, untuk meningkatkan kualitas pembelajaran siswa.

d. Bagi peneliti selanjutnya jika dilakukan penelitian lebih lanjut terhadap model $\mathrm{PjBL}$ untuk materi pembelajaran yang lain, atau melakukan penelitian pada materi yang sama dengan model pembelajaran yang lain.

\section{REFERENSI}

Addiin, I., Redjeki, T. \&Ariani, S.R.D., 2014. Penerapan model pembelajaran project based learning (PjBL) pada materi pokok larutan asam dan basa di kelas XI IPA 1 SMA N 2 karanganyar tahun ajaran 2013/ 2014. Jurnal Pendidikan Kimia Program Studi Pendidikan Kimia Universitas Sebelas Maret, 3(4): 7-16

Becker, K. H., \& Park, K. (2011). Integrative Approaches among Science, Technology, Engineering, and Mathematics (STEM) Subjects on Students Learning: A Meta-Analysis. Journal of STEM Education.

Devi, P. K., Herliani, E., Setiawan, R.,Yanuar,Y. \& Karyana,S. (2018). Materi Bimbingan Teknis Pembelajaran Berbasis STEM Dalam Kurikulum 2013 STEM Mata Pelajaran IPA. Jakarta. Direktorat Pembinaan Sekolah Menengah Pertama

Furi, L.M.I., Handayani, S., Maharani, S. (2018). " Eksperimen Model Pembelajaran Project Based Learning Dan Project Based Learning Terintegrasi Stem Untuk Meningkatkan Hasil Belajar Dan 
Quagga: Jurnal Pendidikan dan Biologi

Volume 11, Nomor 2, Juli 2019

Kreativitas Siswa Pada Kompetensi Dasar Teknologi Pengolahan Susu".Jurnal Penelitian Pendidikan Vol. 35 Nomor 1

Ferdiansyah, I., (2015) ." Perbedaan Hasil Belajar Peserta Didik Menggunakan Pendekatan Sts, Sets, Dan Stempada Pembelajaran Konsep Virus". Universitas Islam Negerisyarif Hidayatullah.

Jauhariyyah, F.R., Suwono, H. \& Ibrohim. (2017). "Science, Tecnology, Engineering and Mathematics Project Based Learning (STEM-PJBL) pada Pembelajaran Sains". Pros. Seminar Pend. IPA Pascasarjana UM, 2:978602-9286-22-9.

Kurniasih, S. (2014). Strategi-Strategi Pembelajaran. Bandung. Alfabeta.

Lukman, L.A., Martini, K.S. \& Utami, B., 2015. Efektivitas metode pembelajaran project based learning (PjBL) disertai media mind mapping terhadap prestasi belajar siswa pada materi pokok sistem koloid dikelas XI IPA SMA Al Islam 1 surakarta tahun ajaran 2013/2014. Jurnal Pendidikan Kimia Program Studi Pendidikan Kimia Universitas Sebelas Maret, 4(1)

Mayasari, T., Kadorahman, A., \& Rusdiana, D. (2014). Pengaruh pembelajaran terintegrasi science, technology, engineering, and mathemathics (STEM) pada hasil belajar peserta didik: Studi meta analisis, Prosiding Semnas Pensa VI "Peran Literasi Sains"

Na'imah, N.J., Supartono., Wardani, S.(2015) "Penerapan Pembelajaran Berbasis Proyek Berbantuan E-Learning Untuk Meningkatkan Hasil Belajar siswa".
p-ISSN 1907-3089, e-ISSN2651-5869

https://journal.uniku.ac.id/index.php/quagga

Siregar, A, (2016). Pembelajaran Pengantar Fisika Kuantum Dengan Memanfaatkan Media Phet Simulation Dan LKM Melalui Pendekatan Saintifik: Dampak Pada Minat Dan Penguasaan Konsep Mahasiswa. Jurnal Ilmiah Pendidikan Fisika Al-BiRuNi

Slameto. (2010). Belajar dan faktor-faktor yang Mempengaruhinya. Jakarta. PT.Rineka Cipta.

Titu, M. A., (2015). "Penerapan Model Pembelajaranproject Based Learning (Pjbl)Untuk Meningkatkan Kreativitas Siswa Padamateri Konsep Masalah Ekonomi”. Prosiding Seminar Nasional

Toto. 2019. "STEM- Based Science Design in the 2013 Curriculum". Journal of Physics. Conference Series. IOP Science. Volume 1233 (1) 012094 